\title{
Vowel weakening in the Sabellic languages as language contact
}

\begin{abstract}
In this article I show that weakening of unstressed vowels in Oscan, Umbrian and Paelignian occurs in different environments and at different points in the relative or absolute chronologies of the individual languages, and produces different results. Consequently, vowel weakening did not take place in Proto- or Common Sabellic as commonly thought, but should instead be seen as the longterm result of the generalisation of an initial stress accent across a number of languages in contact in Ancient Italy, including Latin, the Sabellic languages, and Etruscan.
\end{abstract}

Keywords: vowel weakening, Sabellic, language contact, superlatives, Oscan, Umbrian

\section{Introduction}

The Sabellic language family, an Indo-European subgroup, consists of a number of languages spoken in Ancient Italy, all of which were extinct by around the beginning of the first millennium A. D. The nearest relatives of the Sabellic languages were Latin and Faliscan, ${ }^{1}$ with which they formed a subgroup known as Italic. The relationship between the Sabellic languages and the establishment of a family tree for this Indo-European language group have been a topic of much discussion in recent decades (e. g. Coleman 1986; Meiser 1987; Ignasi J. Adiego Lajara 1992; 1993; Rix 2003; 2009; and now Clackson 2015). In general, this discussion has centred around which isoglosses between languages are to be attributed to shared innovation, and which to parallel innovation or contact. It has long been realised that there are a number of isoglosses between two or more languages which relative chronology shows can only have come into existence after Proto-Sabellic had already split up. These traits have tended to be attributed to a stage called 'Common Sabellic', which can be taken to imply a chronological period between the beginnings of separation between the Sabellic languages and their final separation

1 On the discussion as to whether Faliscan is a dialect of Latin or a closely related language see Bakkum (2009).

Nicholas Zair: Cambridge University; naz21@cam.ac.uk

DOI: 10.1515/if-2016-0016 
(however this is to be defined), in which the languages, while having undergone some minor changes, could be seen as a continuum of (presumably) mutually comprehensible dialects. However, our evidence for, and understanding of, the Sabellic languages has improved immensely over the last thirty years (notably with the edition of the South Picene corpus by Marinetti 1985, the publication of the inscription from Tortora by Lazzarini \& Poccetti 2001, and the editions of Rix 2003 and Crawford et al. 2011), as also for the possible effects of language contact (for introductions to this topic see Thomason 2003 and Hickey 2010). Consequently, it is now clear that there may have been several stages in the split of the Sabellic languages from Proto-Sabellic, and that many of the languages remained in contact for several centuries, resulting in a complicated web of shared developments for which it is often difficult to distinguish between genetic and contact explanations. Indeed, Clackson (2015), following an idea of Garrett (1999), has suggested that similarities between the later-attested Sabellic languages (from about 400 B. C.) should be largely seen as the result of a process of convergence rather than inheritance.

In this article I will argue that the appearance of "weakened" vowels in a number of Sabellic languages, which has previously been seen as a Proto- or at least Common Sabellic development, instead should be seen as independent developments, the weakening in question affecting different vowels in different contexts, and giving different results. Nonetheless, the weakening can be seen as part of a general reduction in vowels in non-initial syllables which is a well-known feature of many of the languages of Ancient Italy, including (at least) some of the Sabellic languages, Latin, and the non-Indo-European Etruscan. This is presumed to be the result of the development of an initial stress accent in all these languages, which was not inherited from Proto-Indo-European by the Italic languages. There is good evidence for contact between speakers of these languages from early in the first millennium B. C., and for the linguistic effects of this contact.

\section{The Sabellic languages}

The Sabellic languages were spoken in Central and Southern Italy in the first millennium B. C. The earliest evidence for this family comes from around the sixth century, most abundantly in the form of the 23 South Picene inscriptions dating between the sixth and fourth centuries; a small number of other early inscriptions are attested, most notably the 6th- or 5th-century “Tortora Inscription” (Blanda 
1/Ps 20), ${ }^{2}$ which, along with a handful of other inscriptions, is often considered to represent a language known as "Pre-Samnite". ${ }^{3}$ Umbrian is attested in a single inscription from the sixth century (Caere 1/Um 4), and otherwise from a handful of inscriptions from around 400 B. C. onwards, and seven bronze tablets called the Iguvine Tables. These fall into two parts, the first written between the late third to the mid-second centuries B. C., in the Umbrian alphabet; the second, from the end of the second or start of the first century, in the Latin alphabet. ${ }^{4}$ We have evidence for Oscan from about the beginning of the fourth century to the first century, which was written using the Oscan alphabet in Campania and Samnium (more or less modern-day Campania), and the Greek alphabet in Lucania (Basilicata) and Bruttium (Calabria). A very small number of Oscan inscriptions use the Latin alphabet. ${ }^{5}$ Paelignian is attested in several dozen inscriptions using the Latin alphabet in the second and first centuries B. C.; there are a number of other languages such as Volscian, ${ }^{6}$ Vestinian and Marrucinian, which are each attested by a handful of inscriptions at most.

As already noted, the relationships between these languages are hard to define, not least because evidence for many features is lacking in some of the attested languages. While some isoglosses presumably go back to Proto-Sabellic (for discussion of phonological examples, see Meiser 1986: 39-107), many seem to be due to subsequent separate developments, as is often shown by relative chronology. Thus, for example, Oscan and Umbrian both re-organised the five-vowel system they had inherited from Proto-Sabellic by merging ${ }^{\star}-\bar{e}-$ and ${ }^{\star}-i-$ as ${ }^{\star}-\breve{e}_{-}$, and ${ }^{\star} \bar{o}_{-}-$

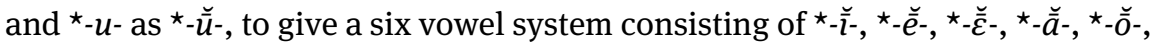
${ }^{\star}-\breve{u}$ - (on the reflexes of ${ }^{\star}-\bar{u}$ - see Meiser 1986: 53; Seidl 1994: 349-351). ${ }^{7}$ This change in the vowel system did not take place in South Picene, where the outcomes of ${ }^{\star}-i-{ }^{\star}-\bar{e}_{-},{ }^{\star}-e-{ }^{\star}{ }^{\star}-u-,{ }^{\star}-\bar{o}$ - and ${ }^{\star}-o$ - are all distinguished (normally as $\langle\mathbf{i}\rangle,\langle\hat{\mathbf{i}}\rangle,\langle\mathbf{e}\rangle,\langle\mathbf{u}\rangle$,

2 Sabellic inscriptions are cited first in the numeration of Crawford et al. (2011), followed by that of Rix (2003), except for Umbrian forms from the Iguvine Tables (IT), which are only quoted from Rix, since they are not included in Crawford's edition.

3 But on the problems involved in using the term "Pre-Samnite" see Crawford et al. (2011: 16, 19 fn. 103); Clackson (2015: 23-24).

4 In this article the Umbrian, Oscan and South Picene alphabets will be written in bold.

5 Including, however, one of our longest Oscan texts, the Tabula Bantina, from Bantia in Lucania. This is a legal code written on bronze and dating to the beginning of the first century B. C. (Crawford 1996: 274-276).

6 Known from a single inscription found at Velletri, no longer to be attributed to the Volsci, according to Crawford et al. (2011: 340).

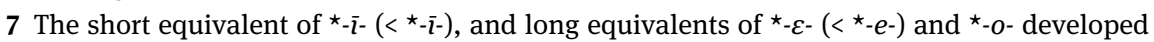
through a variety of secondary processes such as shortening of long vowels and compensatory lengthening. 
$\langle\hat{\mathbf{u}}\rangle$ and $\langle\mathbf{o}\rangle$ respectively); nor does exactly the same system apply in Paelignian (Jiménez Zamudio 1986: 129) or in Volscian (Rix 1992: 233-234), where ${ }^{\star}-\bar{o}$ - and ${ }^{\star}-u$ seem to have fallen together but not ${ }^{\star}-i$ - and ${ }^{\star}-\bar{e}_{-} .{ }^{8}$ Another example is syncope of vowels in medial syllables, which applies in exactly the same environment in (at least) Oscan and Umbrian (short vowels in open syllables, and in closed syllables when followed by ${ }^{{ }_{-}-s-}$-). Nonetheless, this syncope must have taken place after several sound changes which are unique to either Oscan or Umbrian (Benediktsson 1960). Similarly, shortening of long vowels in non-initial (i. e. unstressed) syllables took place in both Oscan and Umbrian. This process took place after the syncope already mentioned, and after other sound changes specific to Oscan and Umbrian, for example, after ${ }^{\star}-u-<^{\star}-u-\left(\right.$ but not ${ }^{\star}-\bar{u}-<^{\star}-\bar{o}-$ ) became [ju] in Oscan (Lejeune 1975: 244-245; Meiser 1986: 135-151; Zair 2014b). ${ }^{9}$

\section{Language contact in Ancient Italy}

Contacts between speakers of the Sabellic languages, Latin and Etruscan seem to have been extensive and prolonged. Apart from the statements of Roman historians, there are other types of evidence, such as the adoption of similar onomastic systems and shared name elements, such as Latin Numerius, Etruscan numesie, Oscan niumsis, Umbrian numesier or Latin Aulus, Etruscan avile/avle, Oscan avl. (Clackson \& Horrocks 2007: 37-49). One effect of the contact can be seen in a number of loan words between the languages (Weiss 2009: 473-476; Wallace 2008: 128-131). Close contact between Latin and the Sabellic languages is implied by the remodelling of the inherited Proto-Indo-European verbal system of present, aorist and perfect stems to a two-stem system, to each of which were built a future, present and past (infectum: future, present, imperfect; perfectum: future perfect, perfect, pluperfect). Some of these new categories seem already to have been created in Proto-Italic, such as the imperfect subjunctive, which is built with a morpheme *-sē- in both Latin foret and Oscan fusíd [be.IMPF.SuBJ.3sG]. However, in the main the same verbal category is expressed with different derivational morphology in Latin and the Sabellic languages (e.g. the future perfect, which is expressed with ${ }^{*}$-is- in Latin but ${ }^{*}-\bar{o} s$ - in the Sabellic languages; see Zair 2014a). This gives the impression of being the result of convergence due to long-term con-

8 For shared morphological innovations in Oscan, Umbrian and other languages, but not South Picene, see Clackson (2015: 26-29); Zair (2014a).

9 Cf. Oscan tiurrí (Pompeii 2, 3/Po 34, 35) 'tower' < *turri- with regatureí 'ruler' (Teruentum 34 A.12, B.15/Sa 1) < ${ }^{\star}$ regatōr-. 
tact and bilingualism (on which see Thomason \& Kaufman 1989: 65-109; Clackson \& Horrocks 2007: 65-74 discuss the situation in Ancient Italy).

Although the greatest evidence for non-inherited shared developments through contact is between Latin and the Sabellic languages, there is at least one feature which was also shared with Etruscan, and which had a long-lasting effect on all these languages; it could be argued that Etruscan should be included as a marginal member of a linguistic area in Ancient Italy. This feature is the reduction and/or loss of vowels in non-initial syllables. In the case of Latin and Etruscan, we have enough evidence to see that this was a slow process, taking place over the course of several centuries. Thus, in Etruscan, confusion in spelling in medial syllables has taken place by the end of the seventh century, resulting in variations of the sort seen in the name avile, avule, avale, avele. By the time of the early fifth century, this name is found spelled avle, and we see total loss of internal vowels in borrowed names such as Greek A $A \varepsilon^{\prime} \xi \alpha \nu \delta \rho \circ \varsigma$ Alexsantre

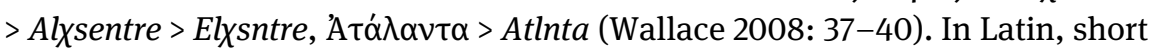
medial vowels in open syllables usually become $-i$-, while ${ }^{\star}$ - $a$ - and ${ }^{\star}$ - $o$ - become $-e$ and $-u$ - respectively in closed syllables. This change is visible in Latin inscriptions after 500 B. C.; subsequently, ${ }^{\star}-o$ - in final syllables followed by a consonant was raised to $-u$ - around the end of the third century; and, lastly, long vowels in final syllables followed by a consonant were shortened, except before -s, around the start of the second century (Weiss 2009: 120-121, 128). Syncope of final short vowels before ${ }^{\star_{-} s}$ took place in all the Sabellic languages as far as we can tell (South Picene meítims, Interamnia Praetuttiorum 1/TE 5 'memorial' < *meitimos, Oscan húrz, Teruentum 34/Sa 1. B 20 'garden' /horts/ < *hortos); whether medial syncope took place in South Picene is unclear (Clackson 2015: 7, but cf. Nishimura 2013: 388-389), but, as already noted, it must have taken place independently in Oscan and Umbrian. These vowel weakenings and syncopes, found in Etruscan, Latin, and the Sabellic languages, are usually explained as being due to the adoption of an initial stress accent. This was certainly not inherited by the Italic languages, since Proto-Indo-European had a free pitch accent. Latin shows no signs of weakening in the earliest inscriptions, and so may not have yet developed the initial accent; we cannot be sure whether it was borrowed from Etruscan, or whether it was a new development there as well.

In the following section, I will discuss the evidence for vowel weakening in the Sabellic languages. Although previous scholars have seen this as a unitary phenomenon applying at a Proto- or Common Sabellic stage, the evidence shows that it took place in different conditions and gave different results in different languages. Furthermore, both relative and absolute chronology suggest a fairly late date for the weakening. Instead, vowel weakening in these languages represents 
another facet of the reduction of vowels characteristic of many of the languages of Ancient Italy.

\section{Defining vowel weakening}

Vowel weakening in the Sabellic languages has not been the subject of much discussion in the scholarly literature, but where it has been discussed it has usually been implicitly or explicitly attributed to Proto- or at least Common Sabellic (e. g. von Planta 1892-1897: 1.237-1.241, 243; Buck 1928: 55-57; Nishimura 2013: 381-386). ${ }^{10}$ The most detailed discussion of the phenomenon is that of Nishimura; he restricts the environment in which vowel weakening occurred to medial vowels before or after a labial consonant, and considers various different spellings of the weakened vowel as reflecting attempts to write a rounded centralised vowel $[\Theta]$ or

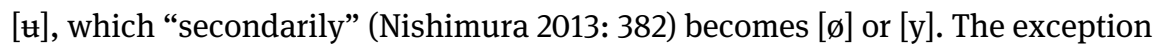
to the view that vowel weakening took place early is Meiser (1986: 33, 268-271), who considers the Umbrian evidence to reflect a purely Umbrian change whereby ${ }^{\star}$ - $a$ - becomes [0], ${ }^{11}$ spelt $\langle\mathbf{a}\rangle$ and $\langle\mathbf{u}\rangle$, in environments where ${ }^{*}$ - $a$ - avoided syncope by analogy. The same variation is found in the reflex of final ${ }^{\star}-\bar{a}$, which is also assumed to have become [o]. Nishimura (2014: 184-185) agrees that some of the Umbrian forms reflect a different rule from his proposed vowel weakening, and sets up two chronological stages. The first is the Common Sabellic change described above, and the second a development similar to that proposed by Meiser, which took place only in Umbrian, between the third and first centuries B. C. whereby *- $a$ - and *-e-became [ə], which was spelt $\langle$ o $\rangle$ in prestota (e. g. IT VIb 57), prestotar (IT VIIa 20, 22, 33, 36), prestote (IT VIIa 6, 8, 24) < prestate (IT Ib 27) 'name of a goddess' < *-statā and tesenocir (IT VIb 1, 3), tesonocir (IT VIa 20, VIIa 38) < tesenakes (IT Ia 11, 14) < tesenakois 'place name', in order to maximally distinguish the vowel from $[\varepsilon]\langle e\rangle$ in the first syllable.

In the next sections I will examine the evidence for vowel weakening in Oscan, Umbrian and the other Sabellic languages, but first it is important to distinguish this evidence from various other kinds of conditioned changes which affected vowels in the Sabellic languages and which should not be included here. The first is the development of * $a$ - to *- $e$ - in open medial and closed final syllables which may have taken place in Proto-Sabellic according to Haug (2004) on the basis of

10 "[V]owel reduction was already operative at a very early stage of Sabellic: 550-500 BCE or earlier” (Nishimura 2013: 386).

11 Meiser uses the symbol [å] to represent this open, back, rounded vowel. 
evidence like Umbrian pruseçetu (IT IIb 12) 'cut up' < *prosekatā < ${ }_{\text {-sekh }}$-teh ${ }_{2}$, Vestinian didet (Incerulae 4/MV 5) 'gives' $<{ }^{\star}$ didat $<{ }^{\star} d i-d h_{3}-t i$. Secondly, the Oscan raising in enclitics of $[\varepsilon]>[\mathrm{e}]$ and $[\mathrm{o}]>[\mathrm{u}]$ found in e. g. tíf[eí] (Cumae 9/Cm 13) 'to you' < *tefei, íst (Abella 1/Cm 1) beside est (Capua 25/Cp 30) < * est, ${ }^{12}$ suveís (Abella 1/Cm 1 A.9, B.9), suvad (Pompeii 16/Po 16), suv(ad) (Pompeii 17/Po 17) 'his/her' beside súvad (Aufidena 2/Sa 18), súv(ad) (Teruentum 9/Sa 16) < *souno-. As the variation in the spelling shows, this raising was an ongoing process in Oscan (note that it does not feed ${ }^{\star}-u->[j u]$ after a dental), and is presumably due to the possibility of treating pronouns and the verb 'to be' as clitics (Nishimura 2013: $383 \mathrm{fn} .8$ ). ${ }^{13}$ Thirdly, we have the raising of [o] to [u] before final [m] in Oscan, as seen in infinitives like fatíum, deíkum (Capua 33/Cp 36), deicum (Bantia 1.10/Lu 1) which come from *-om (cf. tríbarakavúm Abella 1 B.10/Cm 1) and accusative singulars in *-om like dolum (Bantia 1.21/Lu1), dunum (Bouianum or Saepinum not Aesernia 1/Sa 22) beside dolom (Bantia 1.5/Lu 1) and dunúm (Teruentum 20/Sa 24) (Buck 1928: 37; Meiser 1986: 52). A similar raising is found also in South Picene, e. g. múfqlúm (Interamnia Praetuttiorum 1/TE 5) 'monument' < *-om (Weiss 1998). Fourthly, we should discount the instances of -ur-for expected *-or-in Umbrian in forms like curnaco (acc. sg., IT VIa 2, 4, 15, 17) 'crow', tursitu (3sg. fut. impv., IT VIb 60, 7a 49) 'terrify'. This was seen as raising by Meiser (1986: 116) and Untermann (1990: 297), who differ in the precise conditioning factor; I think -ur- may be the regular reflex in Umbrian of * ${ }^{\star}$ - - (Zair forthcoming).

Having excluded these various raising processes, it is now possible for us to examine the remaining evidence for vowel weakening; first that of Oscan, then Umbrian, then the other Sabellic languages will be collected and analysed, before some difficult cases are discussed.

\section{Vowel weakening in Oscan}

The evidence for vowel weakening in Oscan is rather meagre. Most apparent examples are taken from the first-century-B. C. Tabula Bantina, where we find several instances of $\langle u\rangle$ in non-initial syllables where we would expect to find another vowel. The forms are pertumum 'to hinder' (Bantia 1.7/Lu 1) < pertemom < ProtoSabellic * pert-em- beside pertemust (1. 4), pertemest (1. 7); amprufid 'illegally'

12 But see Mancini (1997: 111-113) for arguments against including íst in this evidence. 13 The same raising is found in the possessive pronoun both in Latin suus and in Umbrian (Leumann 1977: 135; Meiser 1986: 116; Meiser 1998: 68, 159; Weiss 2009: 334). Reduction of 'to be' due to enclisis is also a characteristic of Latin (Pezzini 2011). 
(Bantia 1.30/Lu 1) < Proto-Sabellic *amprofēd (cf. Lat. improbē); petirupert 'four times' (Bantia 1.14/Lu 1) < Proto-Sabellic * peturā pert beside petiropert (1. 15); praefucus 'prefect' (Bantia 1.23/Lu 1) beside facus (1. 30). Unfortunately, the Tabula Bantina was not engraved very carefully. Mistakes are fairly frequent, and in particular the engraver's eye occasionally seems to have slipped forward in his text, as for example in sansae tautam for Bansae toutam (1.19) 'the people at Bantia' and phim pruhipid for pim pruhipid (1. 25) 'he may not prevent anyone'. Consequently, one might be cautious about pertumum and praefucus, where there is a $\langle\mathbf{u}\rangle$ in the following syllable. Similarly, petirupert is directly followed in the same line by urust 'he will have pleaded'. There are, however, also occasional forms found in other inscriptions which seem to show the same development, although these are often uncertain. The best case in the Oscan alphabet is fatuveís (Aeclanum 1/Hi 6), which is cognate with Lat. Fatuus, an epithet of Faunus as god of oracles, and perhaps also Lat. fatuus 'silly'. It is probably derived from a tu-stem, and comes from Proto-Italic ${ }^{\star}$ fa-teu-o- > Proto-Sabellic ${ }^{\star}$ fatouo- (Untermann 2000: 268; de Vaan 2008: 205). A possible further example is prupukid (Abella 1/Cm 1 A.2) 'by common agreement (?)', if this comes from * prūpak-< Proto-Sabellic * prō-pakas usually assumed (see Untermann 2000: 587 for bibliography). However, the meaning of this hapax is not certain; even if that given above is more or less correct, a reconstruction ${ }^{\star} p r \bar{o}-p \bar{o} k$ - $<$ Proto-Indo-European ${ }^{\star}-p_{0} h_{2} k$ - is not entirely ruled out (though disfavoured by Weiss 1993: 36-39). Another instance may be aflukad (Capua 34.3/Cp 37), whose meaning and etymology are exceedingly uncertain (see Untermann 2000: 58, 59 and Mancini 2006); although various etymologies have been suggested, the main reason for thinking that it represents a case of weakening is the existence of the form aflakus in 1.11 of the same inscription. However, although it is tempting to assume that the two verbal forms should be etymologically related, this is not necessarily the case (and is doubted by both Untermann and Mancini). Even if they do come from the same root, it is possible that this could have been something like ${ }^{\star} l e h_{3} k$-, which would give a full grade ${ }^{\star} l o \bar{k}$ - and a zero grade $\star l a ̆ k$ -

All the possible instances of weakening of vowels in Oscan take place in noninitial and non-final open syllables next to a labial. ${ }^{14}$ The most straightforward analysis of the consistent use of $\langle\mathbf{u}\rangle$ in the Latin alphabet and $\langle\mathbf{u}\rangle$ in the Oscan alphabet is that the resulting vowel was felt to be nearest to $/ \mathrm{u} / \mathrm{cf}$. /o/, which was spelt $\langle\mathbf{0}\rangle$ and $\langle\hat{\mathbf{u}}\rangle)$, although it could of course be any rounded, relatively close vowel, such as $[\Theta]$ or $[\mathrm{t}]$. It affects Oscan $[\mathrm{a}]<^{\star}-a-,[\varepsilon]<{ }^{\star}-e-$, and $[0]$ (from ${ }^{\star_{-}-o-}$ and

14 If aflukad does belong here, the labiality of the $-f$ - in the previous syllable must have been enough to cause the change. 


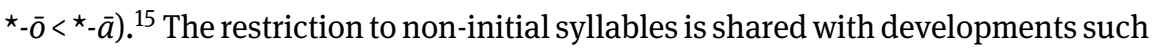
as syncope and vowel-shortening discussed in Section 3. A plausible explanation of the weakening seen in Oscan is reduction of duration of vowels in unstressed syllables. Since higher vowels tend to have shorter duration, this is liable to lead to raising (Flemming 2004: 244-248; Barnes 2006: 29-30; Sen 2012: 465-466, 474-478). Apparently, the lack of stress did not affect the realisations of the vowels enough to be reflected in writing, except when there was the further conditioning factor of lip-rounding in an adjacent consonant, in which case the reduced and hence higher and more rounded vowel could be analysed as [u] (or at least closest to $[u])$. Even in this environment, writing of the weakened vowel as $\langle\mathbf{u}\rangle$ or $\langle\mathbf{u}\rangle$ is sporadic at best. Even in the Tabula Bantina, by no means all vowels next to a labial are spelt $\langle\mathbf{u}\rangle$; in addition to the forms like pertemum and petiropert mentioned above, there are many cases like fefacid (l.10) 'he should act', fefacust (l. 11) 'he will have acted', censamur (1.19) 'he is to be listed', lamatir (1. 21) 'let him be flogged', famelo (1. 22) 'estate', etc. It is possible that the development to [u] (or [e] etc.) was only phonetic at this stage. At any rate, the underlying phoneme was normally written, which would have been easily identified due to other parts of the verb or noun paradigm where it was preserved due to being in a non-medial or closed syllable (e. g. pertemust beside *em-, cf. Umbrian emantur IT Va 8; praefucus beside facus; petirupert beside * peturo).

\section{Vowel weakening in Umbrian}

The Umbrian alphabet does not distinguish between [u] and [o], so we cannot tell which vowel is represented in prehubia (IT Va 12) 'he should put forward' < *-habea < Proto-Sabellic *-habēāt (beside prehabia IT Va 5, habia e. g. IT Va 17), perhaps ařputrati (IT Va 12) 'decision' (abl. sg.) (although the etymology is unclear: Untermann 2000: 53-3; de Vaan 2008: 50). In the Latin alphabet, however, this vowel is usually written with $\langle 0\rangle$ : comoltu (IT VI b 17, 41, VIIa 39, 44, 45), kumultu (IT Ia 34) 'grind thoroughly' < *-maltu < ${ }^{\star}$-maletōd (beside kumaltu e.g. IT IIa 9); the divine name prestota (e. g. IT VIb 57), gen. sg. prestotar (IT VIIa 20, 22, 33, 36), dat. sg. prestote (IT VIIa 6, 8, 24) < *statā (beside prestate IT Ib 27); the toponymic adjective abl. pl. tesenocir (IT VIb 1, 3), tesonocir (IT VIa 20, VIIa 38) beside tesenakes (IT Ia 11, 14); atropusatu (IT VIb 36) 'perform a tripudium'

15 According to von Planta (1892-1897: 1, 237-241, 243), only [a] and [o] were affected, but pertumum demonstrates that $[\varepsilon]$ was also affected. 
< ${ }^{\star}$ atrepuđatu $<{ }^{\star} \bar{a}$-tri-pud- $\bar{a}-t \bar{o} d^{16}$ (beside ahatripursatu IT VIIa 23, atripursatu IT VIb 16 , ahtrepuřatu IT IIa 24, 25, 31, 38, atre\{:\}puřatu IT IIb 18); perhaps amboltu (IT VIb 52)‘?’ if from*-altu < *aletōd (Untermann 2000: 84-85).

Looking first at the data with ${ }^{\star}-a$-, we find variation between $\langle\mathbf{a}\rangle$ and $\langle\mathbf{u}\rangle$ in the Umbrian alphabet, and consistent $\langle\mathbf{0}\rangle$ in the Latin alphabet. As already discussed in section 4, Meiser (1986: 33, 268-271) attributes this to a change of *- $a$ - to [0], which is also the result of word-final original long ${ }^{\star}-\bar{a}$. I would be inclined to suppose that Proto-Sabellic ${ }^{\star}-a$ - was already something like [v]. The long ${ }^{\star}-\bar{a}$ - was perhaps slightly more closed; at any rate, in absolute final position it became raised to [o] and fell together with /o/ in Oscan (Zair 2016: 56-57). In Umbrian, in final position it is found spelt with both $\langle\mathbf{a}\rangle$ and $\langle\mathbf{u}\rangle$ in the Umbrian alphabet, and $\langle\mathbf{o}\rangle$ in the Latin alphabet (Meiser 1986: 266-267). This suggests a period of uncertainty as to whether to spell the raised result of ${ }^{\star}-\bar{a}$ (perhaps [0]) with $\langle\mathbf{a}\rangle$ or $\langle\mathbf{u}\rangle$ followed by eventual falling together with /o/, perhaps by the time the latest portions of the Iguvine tables in the Umbrian alphabet were written (Meiser 1986: 267). The same can have happened with unstressed ${ }^{\star}-a$-, with raising being the result of reduction in an unstressed syllable, although the final falling together with /o/ seems to have happened slightly later, since there are still spellings with $\langle\mathbf{a}\rangle$ in tables Ib 10-IIa 14, which otherwise spell *-à consistently with $\langle\mathbf{u}\rangle$ (Meiser 1986: 266-267, 271).

As shown by the weakening in kumultu $<{ }^{\star}$-maletōd, which is however never found in the frequent past participle kumates (e. g. IT IIa 42), comatir (e. g. VIb 17) $<^{\star}$ mal-to-), weakening, at least of ${ }^{\star}$ - $a$-, is limited to syllables that were open before the process of medial syncope. ${ }^{17}$ As already noted, Nishimura suggests that unstressed vowels were weakened in labial environments already in Common Sabellic, and ${ }^{\star}$ - $a$ - and ${ }^{\star}-e$ - in a non-labial environment within Umbrian itself. This is a possible interpretation of the evidence, but because of the variation in the Umbrian alphabet between the spellings $\langle\mathbf{a}\rangle$ and $\langle\mathbf{u}\rangle$ for ${ }^{*}-a$ - there is little positive evidence for it: while it is true that most examples of the spelling with $\langle\mathbf{u}\rangle$ are in a labial environment, the use of $\langle\mathbf{a}\rangle$ in the single example of prestate and two examples of tesenakes could still represent [ग]. Furthermore, no weakening seems yet to have taken place in ahtrepuřatu, atre $\{$ : $\}$ puřatu, despite the [e] being next to a labial.

Beside these cases of ${ }^{\star}$ - $a$-, we find only one instance each of $[\varepsilon]<{ }^{\star}-e$ - and $[\mathrm{e}]$ from ${ }^{\star}-i$ - being written $\langle 0\rangle$ in tesonocir and atropusatu respectively. Given the very small number of examples, it is difficult to know what to do with this evidence. The

16 For the vowel in the root ${ }^{\star}$-pud- see below, in this section.

17 Thus Meiser 1986: 271. 
change in these words is considered irregular by Meiser (1986: 271-272), and in the case of tesonocir we might wonder if the first $\langle 0\rangle$ is due to eye-skip to the following $\langle 0\rangle$ by the engraver. But there is no such explanation for atropusatu. If tesonocir and atropusatu are in fact examples of vowel weakening, this may be the result of a secondary change, slightly different from that supposed by Nishimura. The development of * $a$ - seems to be more or less regular, insofar as the evidence allows us to tell. Since vowels in open syllables were lost in Proto-Umbrian, *- $a$ - was only preserved in this environment due to paradigmatic analogy. Consequently, there are very few examples, but most of those for which we have evidence in the Latin alphabet are spelt with $\langle 0\rangle .{ }^{18}$ By comparison, the only instances of analogically preserved ${ }^{\star}-e$ - and ${ }^{\star}-i$ - which are written $\langle 0\rangle$ are tesonocir and atropusatu; compare, for example, proseseto (IT VIa 56) 'cut up' < ${ }^{\star}$ proseketā, which is attested, along with other parts of the paradigm, 14 times in the Latin alphabet, but never has its penultimate vowel spelt $\langle 0\rangle$. As in the Oscan case, we may have here a phonetic development which is often not represented in writing; in tesonocir and atropusatu it is likely that it was harder to identify the underlying phoneme since there was no strong evidence from elsewhere in the paradigm; the back rounded vowels in the following syllable may have been responsible for the spelling $\langle 0\rangle$ in both cases (the presence of a labial could be a further conditioning factor for atropusatu).

The single exception to the spellings with $\langle\mathbf{a}\rangle$ or $\langle\mathbf{u}\rangle$ and $\langle 0\rangle$, suggesting values [0] and then [o] for *-a-, seen so far, is in the third syllable of atropusatu, ahatripursatu, ${ }^{19}$ atripursatu, with $\langle\mathrm{u}\rangle$ rather than $\langle 0\rangle$. It is usually assumed that this vowel

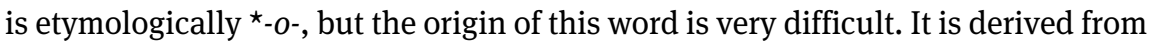
the word attested in Latin as tripudium 'a ritual dance in triple time; the noisy falling to the ground of corn fed on by the sacred chickens', which is usually taken to have come from *tri-pod-iino-, being related to the word for 'foot' (Untermann 2000: 62-63; de Vaan 2008: 462). But this ought to have given ${ }^{\mathrm{x}}$ tripidium by Latin vowel weakening, ${ }^{20}$ and there is no satisfactory explanation for the divergent development here; the semantics are also difficult, as discussed below. According to Sommer \& Pfister (1977: 85), tripudium is due to recomposition as *tripodiom after vowel weakening, whence, by a further round of weakening, tripudium. ${ }^{21}$ But this secondary change is ad hoc, being otherwise only found in repudium 'rejection, divorce', also based on * podiom, according to Sommer \& Pfister. It is also unclear what the synchronic basis for such a recomposition might have been:

18 For explanations of possible exceptions, see Meiser (1986: 271).

$19 a h a$ - in this form is a way of writing [a:].

20 Weakening of -o- to - $u$ - normally takes place only in closed syllables (Weiss 2009: 116-117).

21 Presumably this is also what Leumann (1977: 392) has in mind; Weiss (2009: 118) merely refers to "secondary origin". 
the only plausible sources are the Greek loan-words podium 'an elevated height', which does not have the right semantics, and tripūs, -odis 'three-footed seat', a connection with which might have been possible for tripudium, but hardly for repudium.

For repudium, the better etymological connection is probably with pudeo 'I am ashamed' (Walde \& Hofmann 1938-1956: 2.381-2.382; Ernout \& Meillet 1985: 571; de Vaan 2008: 496), which would then provide the basis for the retention of the unweakened vowel in the compound (the connection was still felt by the grammarian Verrius, as reported by Festus; Lindsay 1913: 350). For tripudium, the connection with * pod- is also problematic semantically: while it explains the meaning 'solemn religious dance', it is hard to see the connection with the chickenfeed omen. What both of these meanings have in common is the idea of things striking the ground rather than 'feet', and this is certainly the concept that was uppermost in the minds of Cicero (Div. 2.72) and Festus (Lindsay 1913: 284, 498) who offer etymologies derived from terra 'earth' and pauio 'strike'. The only strong reason to associate tripudium with a root * pod- is the forms tripodauerunt and tripodationem in the Acta Arvalia (CIL: 6, 2104a). But these forms are not in the apparently ancient Carmen Arvale, but in the surrounding text of the inscription, which dates to 218 A. D., and which was not carefully inscribed, with frequent errors (Gordon 1951: 88). Consequently, I suspect that the composer or inscriber of the inscription misspelt this technical and unusual word, perhaps under the influence of tripūs, -odis. Given the problems involved, I do not think we can be sure that the "root" at the basis of tripudium and atropusatu is *pod-rather than

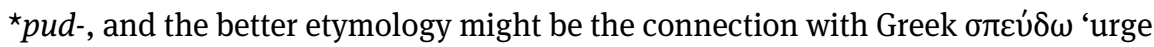
on, press on, hasten', Lithuanian spáusti 'push, press, hurry' and Greek $\pi v \delta \alpha \rho i ́ \zeta \omega$ 'dance the fling' (Walde \& Hofmann 1938-1956: 2.205-2.206; Beekes 2010: 1254). ${ }^{22}$ An original meaning to the root of 'slap' or 'beat' would do well to explain the forms in Latin and the other languages. In this case, the Umbrian forms would show the original vocalism. ${ }^{23}$

22 I am grateful to Jouna Pyysalo for pointing out to me the existence of $\pi v \delta \alpha \rho i \zeta \zeta \omega$. The same root may in fact also lie behind pudeō and repudium (de Vaan 2008: 496).

23 The failure of vowel-weakening in tripudium remains a problem, of course. The only explanation for its failure to undergo weakening that occurs to me is the retention of the original form in highly formulaic and conservative ritual language. 


\section{Vowel weakening in the other Sabellic languages}

There may be evidence for vowel weakening in other Sabellic languages, although

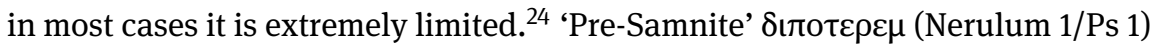

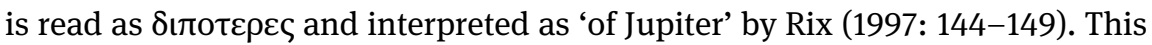
would give $\langle 0\rangle$ for ${ }^{\star}$ - $a$ - in *-patereis. But, as noted by Crawford et al. (2011: 1341), there is no warrant for reading final $\langle\mu\rangle$ as $\langle\varsigma\rangle$, and consequently the meaning and etymology of this form are uncertain (although, as Rix observes, the final $-\mu$ is very hard to interpret, and Crawford et al.'s (2011) attempt, attributed to Clackson, to explain the form, is unpromising). If the $\langle\mathbf{o}\rangle$ in this form were due to vowel weakening, we could not be sure, given the absence of examples of Proto-Sabellic ${ }^{\star}$ - $u$ - in this inscription, whether the weakened vowel must be [o], or whether it could also be $[\mathrm{u}]$.

Paelignian is the only other Sabellic language in which there is a certain amount of evidence for vowel weakening, which consists of hospus (Sulmo 13/Pg 11) 'stranger' < Proto-Sabellic *hosti-pot-s (Untermann 2000: 335-336) and hanustu (Corfinium 6/Pg 9), if this means 'honoured', from *hanostā (cf. Latin honor, honestus; Untermann 2000: 317). ${ }^{25}$ If both examples here are reliable, Paelignian seems to show a weakening of ${ }^{\star}-o$ - to $[u]$ like Oscan (note that, as in the Tabula Bantina, Paelignian orthography represents $[\mathrm{u}]<{ }^{\star}$ - $u$ - and ${ }^{\star}$-o - with $\langle\mathrm{u}\rangle$; Jiménez Zamudio 1986: 121, 123-124). Unlike in Oscan, the weakening seems to take place in closed syllables (in hanustu), but as discussed in Section 2, closed syllables ending in

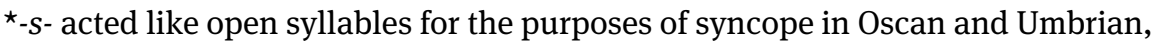
so it is possible that this is also the case for vowel weakening. Since we have no evidence for this environment in Oscan, we cannot be sure that it would not have taken place here also. In hospus, weakening seems to have taken place in a final syllable, but this could be due to levelling from parts of the paradigm such as gen. sg. *-pot-os in which it was in a medial syllable. However, if hanustu is reliable, Paelignian vowel weakening is different from that of Oscan in taking place when the vowel was not preceded or followed by a labial.

24 The origin of the vowel in the final syllable of South Picene estuf (Interamnia Praetuttiorum 1/TE 5) and estufk (Asculum Picenum 2/AP 2) 'here', Paelignian ecuf (Corfinium 11/Pg 10), Marrucinian ecuf (Teate Marrucinorum 6/MV 8) 'here' is not certainly *-o- rather than *- $u$ - (Untermann 2000: 237-238, 215-216; Dupraz 2012: 291; Nishimura 2013: 383-384).

25 The imperfect subjunctive upsaseter, also mentioned by Jiménez Zamudio (1986: 14, 121), has $\langle\mathrm{u}\rangle=[\mathrm{u}:]<^{\star}{ }^{-} \bar{o}^{-}$, by analogy with the perfect stem in ${ }^{\star} \bar{o} p s-($ Rix 1993). 


\section{Remaining evidence}

So far the evidence from Oscan, Umbrian and Paelignian has shown rather cleancut distinctions: in addition to some differences in the environment in which weakening has taken place, there is also a strong distinction between Oscan (and Paelignian, as far as we can tell), where the result of weakening is always [u] (or at least a reasonably close rounded vowel), and Umbrian, where, at least for $\star^{*} a$-, it seems to have been [0] and later [o]. However, these results are somewhat artificial, insofar as some evidence that is usually considered as part of the data for vowel weakening has thus far been omitted. These forms, which reflect a unitary environment consisting of the vowel that developed from a syllabic *-m- before vowel in Proto-Italic, are collected and discussed here, and it will be shown that they are not relevant to vowel weakening, but rather reflect the regular reflex of *-m- in this environment.

We have evidence in the Sabellic languages for syllabic *-mo- before a vowel from two sources, both inherited from Proto-Italic: superlatives in *-t-mo- (e. g. Latin optimus 'best') and *-is-moo- (e. g. Latin facillimus 'easiest' < ${ }^{\star}$ fakil-is-moo-), and adjectives deriving from some numerals (e. g. Latin decimus 'tenth' < *dekm-o-, cf. decem 'ten' $<{ }^{\star} d e k m$ ). The latter is found in the Palaeo-Umbrian name setums 'Septimus' ([Caere 1]/Um 4) < ${ }^{*}$ septm-o-, while superlatives are attested in several Sabellic languages: Oscan últiumam (Capua 22/Cp 31) 'furthest', Umbrian hondomu (IT VIa 9, 10) 'lowest' contain the *-t-mo- suffix, while 'Pre-Samnite'

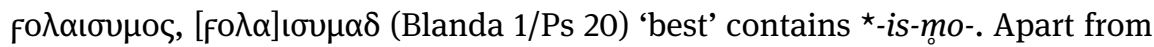
Oscan nesimum, nessimas, Umbrian nesimei 'nearest', which is of unclear derivation, as we shall see shortly, the vowel that results from pre-vocalic *-m- is, or at least can be, consistent across all forms and languages: Oscan $\langle\mathbf{u}\rangle$ must represent $[u]$, and, as far as one can tell, this is also the value of $\langle\mathbf{u}\rangle$ in setums and $\langle\mathbf{v}\rangle$

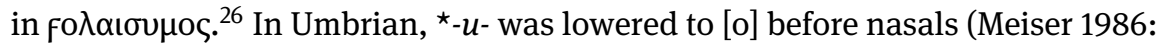
120-122), so hondomu could have come from *hondumo- as well as *hondomo-. Although this vowel is the same as that resulting from vowel weakening in Oscan, the Palaeo-Umbrian form, dating from before the pre-nasal lowering rule, shows that the outcome there is also $[\mathrm{u}]$, which is different from the vowel weakening

26 In [Caere 1]/Um 4, $\langle\mathbf{u}\rangle$ presumably represents [u], since [o:] is written with $\langle\mathbf{o}\rangle$ in míom 'me' ${ }^{\star} m \bar{e}-\bar{o} m$. The Tortora inscription seems to distinguish between ${ }^{\star}-u-$, which is spelt $\langle\mathbf{v}\rangle$ (fufufo $\delta$,

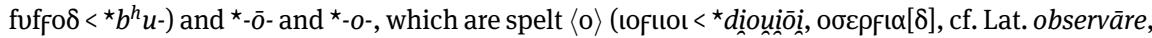

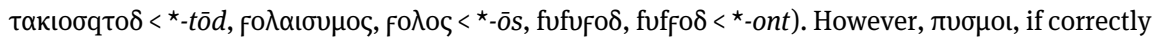
divided and understood, looks as though it belongs with Umbrian pusme, South Picene posmúi 'to whom' $\left\langle{ }^{\star} k^{w} o-s m-o i j\right.$, so it is possible that in some contexts $\langle v\rangle$ can be used to write ${ }^{\star}-o-$. 
output [0]/[o] in Umbrian. Furthermore, although the quality of the vowel is the same in Oscan, nonetheless the ${ }^{\star}$ - $u$ - that derives from ${ }^{\star}$ - $m$ - is different from the $[u]$ that comes from vowel weakening, since it feeds the rule ${ }^{\star}-u->[j u]$ after a dental, as shown by últiumam < oltumām, whereas [u] from vowel weakening does not, as shown by fatuveís $<\star$ fatouein.

The only support for an explanation of these forms on the basis of vowel weakening is the unique vowel [i] in the second syllable of Oscan nesimum (Bantia 1.17, 31/Lu 1), nesimois (Bantia 1.25/Lu 1), nessimas (Capua 29/Cp 24), nessimas (Capua 22/Cp 31), Umbrian nesimei (IT VIa 9) 'nearest'. According to Nishimura, the spelling $\langle\mathbf{i}\rangle,\langle\mathbf{i}\rangle$ in this word is an attempt to write 'secondary' [ø] or [y]. But of all the evidence for weakened vowels, this is the only case of a spelling with $\langle\mathbf{i}\rangle$ or $\langle i\rangle$ rather than a sign for a back vowel, and he does not give any explanation of what would be the reason for the development of 'secondary' [ø] or [y] only in this word. ${ }^{27}$ This being the case, I would argue that such an explanation for consistent $\langle i\rangle,\langle i\rangle$ in the single same lexeme across both Oscan and Umbrian is intrinsically suspect. Other explanations are in fact possible, and to be preferred. According to Cowgill (1970: 132, 136-140), nesimum etc. comes from Proto-Italic * nesd-is-mo- > *nedsisVmo- > *nessismo- > nessimo-; if he is correct, the vowel of the second syllable is simply the regular reflex of the superlative suffix *-is-mo-. Nishimura (2005: 171-173) objects to the sporadic metathesis required to get from *nesd- to *neds-, and reconstructs instead *ned-tmo-, which ought to give *nessumo- if * ${ }^{\star}$ um- is the regular result of ${ }^{\star}$-m - as suggested here. If Nishimura's reconstruction is preferred, I would explain the attested forms as due to replacement of *-umo- by *-imo- $<{ }^{\star}$-isumo-, as seen in Oscan maimas 'greatest' (Bantia 1.3/Lu 1), ualaemom (Bantia 1.10/Lu 1) (on the origins of this suffix see Cowgill 1970: 137-140; Nishimura 2005: 162-171, 178-180). Once ${ }^{\star}-m$ - had become ${ }^{\star}$-um-, Common Sabellic would have had two superlative suffixes: *-tumo- < *-t-mo- and ${ }^{\star}$-immo- < ${ }^{\star}$-is $(u) m o-<{ }^{\star}$-is-mo-. After -dt- > ${ }^{\star}$-ss-, ${ }^{\star}$ nedtmo- $>{ }^{\star}$ nessumo- would not have obviously belonged to either type and was 'corrected' to 'regular' *nessimo-.

27 Buck (1928: 55) suggests the conditioning factor is the vowel of the preceding syllable, but that the distribution was obscured by the influence of related forms; clearly, there is no way of testing this hypothesis, at least with the small amount of data currently available to us. As noted by Nishimura (2004: $244 \mathrm{fn}$. 31), 'Palaeo-Umbrian' setums has the same vowel in the first syllable as nesimum etc. 


\section{Relative and absolute chronology}

The evidence for vowel weakening in the Sabellic languages seems to suggest that different processes took place in the different languages, although all of them targetted non-initial short vowels in open syllables. In Oscan [a], [ع], and $[\mathrm{o}]$ underwent raising and rounding to give $[\mathrm{u}]$ in open syllables before or after a labial. In Umbrian, *- $a$-, probably already [p], was raised in open syllables to [0], perhaps eventually becoming [o]. There may also have been a second, later, development of $[\varepsilon]$ and $[e]$ also to [o]. The presence of an adjacent labial consonant is not required for the Umbrian change (prestota etc., tesonocir etc.). In Paelignian, as far as the evidence is reliable, weakened vowels became $[u]$ as in Oscan, but unlike Oscan did not require a labial environment.

In addition to the differences in output and environment, relative chronology shows that weakening must have taken place separately in the individual languages. As already mentioned, vowel weakening took place in Oscan after the development of ${ }^{\star}$ - $u$ - to [ju] after a dental, as shown by fatuveís (not ${ }^{x}$ fatiuveís). It is also likely that it took place after shortening of long vowels in Oscan, as shown by the fact that it affected original ${ }^{\star_{-}} \bar{a}>^{\star_{-}} \bar{o}>^{\star_{-} o}$ in petirupert $<$ petiropert $\left\langle{ }^{\star}\right.$ petur $\bar{a}$ pert. ${ }^{28}$ That weakening took place only after shortening of ${ }^{\star_{-}} \bar{o}$ to ${ }^{\star_{-} o}$ is plausible on general linguistic grounds: phonetically, the increased duration of long vowels ought to inhibit raising, and indeed usually does: "vowel contrasts are neutralized in short, unstressed syllables" (Flemming 2005: 5; see also Barnes 2006: 93-94, and implied passim). Weakening affecting short but not long vowels would also fit in with the general resistance of long vowels to reduction phenomena in the Sabellic languages and in Latin, all of which underwent changes of this sort in unstressed syllables during the first millennium B. C.: as noted in Section 3, syncope in Oscan and Umbrian affected only short vowels; the same is true of Latin vowel weakening. On the basis of these pieces of evidence we can set up the following relative chronology of sound changes for Oscan, which was already separate from Proto-Sabellic: ${ }^{\star}-u->[j u]$ after a dental $\rightarrow$ Loss of vowel length in non-initial syllables $\rightarrow$ Vowel weakening. ${ }^{29}$ I would date ${ }^{*}-u->[j u]$ to the first half of the fourth century B. C., and loss of vowel length to the second half of that century (Zair 2014b: 119-120), so we can give an absolute date of not much before 300; this would be the date of our earliest possible example of vowel weakening, aflukad (Capua 34.3/Cp 37). If aflukad is not the result of vowel weakening, it might rather

28 The suffix -pert must have been a separate word at the time when ${ }^{\star}-\bar{a}$ became ${ }^{\star}-\bar{o}$, since this change only affected absolute word-final *-a (Meiser 1986: 44).

29 The development of [ju] from ${ }^{\star}-u$ - took place before vowel shortening, as noted in section 2. 
have occurred later, since our next earliest example, fatuveís (Aeclanum 1/Hi 6) occurs in an inscription of c. 150 B. C.

In Umbrian the weakening of * $a$ - to [0] must have taken place prior to medial syllable syncope, a change which took place separately in the individual Sabellic languages but before our earliest evidence for Umbrian. However, weakening of $[\varepsilon]$ and [e], if it took place at all, may have happened between the writing of the earlier and later Iguvine Tables, that is, between the early third and late second centuries B. C. There is no evidence for a relative chronology of weakening in Paelignian: it must have taken place prior to around 100 B. C., the date of both Sulmo 13/Pg 11 and Corfinium 6/Pg 9.

\section{Conclusion}

Weakening of non-initial vowels in Oscan, Umbrian and Paelignian took place in different environments in each language, and the vowel that resulted from weakening was different in Oscan and Paelignian from that in Umbrian; within each language, however, the writing of the resulting vowel was consistent. ${ }^{30}$ Relative chronology shows that vowel weakening in Oscan and Umbrian must have taken place after sound changes specific to each language; this is backed up by the late appearance of vowel weakening in our Oscan texts.

As a result of this evidence, we cannot attribute vowel weakening of this type to Proto-Sabellic, or to Common Sabellic, at least insofar as this is defined as reflecting a relatively undifferentiated dialect continuum, with just a few changes separating the Sabellic languages. Instead, it must have taken place in parallel in Oscan,

30 A reviewer suggests to me that it is possible that there was a general weakening in Common Sabellic of vowels in open syllables to something like [ə], which was then represented in different ways in the different orthographies of Oscan, Umbrian and Paelignian. In principle this is possible: we could suppose that as an allophone of the various phonemic vowels in Oscan it was not written, except where it was additionally rounded by adjacent labials, and it is only the rounding that did not take place until after fronting of ${ }^{\star}$ - $u$ - after a coronal. But petirupert (if it is reliable) requires weakening to have taken place after shortening of long vowels, which happened during the history of Oscan. And, if, as is probable, we should ignore aflukad, there are no instances of weakening prior to c. 150 B. C., which also seems striking. For Umbrian, on the other hand, the evidence suggests that in the first place only * $a$ - was affected there, while Oscan seems to show weakening of $[0]$ and $[\varepsilon]$ as well. If the development were to [ə], I would also be surprised by the consistency with which it is represented by either the etymological vowel or $\langle\mathbf{u}\rangle$ in the Umbrian alphabet, and $\langle 0\rangle$ in the Latin alphabet, by comparison with the general uncertainty of how to write /e/, another vowel for which neither orthography provided a clear model (Meiser 1986: 27). Compare also the variation in spelling of the weakened vowel in Etruscan, as discussed in section 3. 
Umbrian and perhaps Paelignian at a relatively late stage in the development of the languages. We should consider it as part of a picture of much longer-lasting contact between a wide variety of languages of Ancient Italy, including the Sabellic languages, Latin, and the non-Indo-European Etruscan. The main linguistic effect of this contact which arose in all of these languages was the development of an initial stress accent, followed by reduction or loss of vowels in non-initial syllables. Vowel weakening in Oscan, Umbrian and perhaps Paelignian can now be seen as further evidences of the consequences of being a member of the linguistic area that developed in Ancient Italy.

Acknowledgment: I am grateful to James Clackson, who read an earlier draft of this article and gave me helpful advice, and to an anonymous reviewer; also to the attendees of Sound of Indo-European 3 at Silesian University, Opava and Language Contact: State of the Art at Helsinki University in 2014, who provided me with helpful questions and feedback on this topic. The research for this article was supported by the Arts and Humanities Research Council, as part of the 'Greek in Italy' Project.

\section{Abbreviations}

CIL Eugenius Bormann et al., eds. (1876-1980). Corpus Inscriptionum Latinarum. Berolini: Reimerum \& De Gruyter.

\section{Bibliography}

Adiego Lajara, Ignacio J. (1993). "Parentesco, contacto e innovacion paralele: el caso de las lenguas sabelicas". In: Incontri Linguistici 16, 93-104.

Adiego Lajara, Ignasi J. (1992). Protosabellio, Osco-Umbro, Sudpiceno. Barcelona: PPU.

Bakkum, Gabriël C. L. M. (2009). The Latin Dialect of the Ager Faliscus. 150 Years of Scholarship. Amsterdam: Amsterdam University Press.

Barnes, Jonathan (2006). Strength and Weakness at the Interface. Positional Neutralization in Phonetics and Phonology. Berlin \& New York: Mouton de Gruyter.

Beekes, Robert S. P. (2010). Etymological Dictionary of Greek. With the assistance of Lucien van Beek. 2 vols. Leiden \& Boston: Brill.

Benediktsson, Hreinn (1960). “The vowel syncope in Oscan-Umbrian”. In: Norsk Tidsskrift for Sprogvidenskap 19, 157-295.

Buck, Carl D. (1928). A Grammar of Oscan and Umbrian. With a Collection of Inscriptions and a Glossary. 2nd ed. Boston: Ginn \& Company. 
Clackson, James (2015). “Subgrouping in the Sabellian branch of Indo-European”. In: Transactions of the Philological Society 113, 4-37.

Clackson, James \& Geoffrey Horrocks (2007). The Blackwell History of the Latin Language. Malden \& Oxford: Blackwell.

Coleman, Robert (1986). "The central Italic languages in the period of Roman expansion”. In: Transactions of the Philological Society 85, 100-131.

Cowgill, Warren (1970). "Italic and Celtic superlatives and the dialects of Indo-European". In: Indo-European and Indo-Europeans. Papers presented at the Third Indo-European Conference at the University of Pennsylvania. Ed. by George Cardona \& Alfred Senn. Philadelphia: Univ. of Pennsylvania Press, 113-153.

Crawford, Michael (1996). Roman Statutes. London: Institute of Classical Studies, University of London.

Crawford, Michael et al. (2011). Imagines Italicae. A Corpus of Italic Inscriptions. London: Institute of Classical Studies.

De Vaan, Michiel A. C. (2008). Etymological Dictionary of Latin and the Other Italic Languages. Leiden \& Boston: Brill.

Dupraz, Emmanuel (2012). Sabellian Demonstratives. Forms and Functions. Leiden \& Boston: Brill.

Ernout, Alfred \& Antoine Meillet (1985). Dictionnaire étymologique de la langue latine. Histoire des mots. 4th ed. Paris: Klincksieck.

Flemming, Edward (2004). “Contrast and perceptual distinctiveness”. In: Phonetically Based Phonology. Ed. by Bruce Hayes, Robert Kirchner \& Donca Steriade. Cambridge: Cambridge University Press, 232-276.

Flemming, Edward (2005). A phonetically-based model of phonological vowel reduction. Manuscript. URL: washo.uchicago.edu/seminar/Flemming2005\%5C_VowelReduction.pdf.

Garrett, Andrew (1999). “A new model of Indo-European subgrouping and dispersal”. In: Proceedings of the Twenty-Fifth Annual Meeting of the Berkeley Linguistics Society. Ed. by Chang. Steve S., Lily Liaw \& Josef Ruppenhofer. Berkeley: Berkeley Linguistics Society, February 12-15, 146-156.

Gordon, A. E. (1951). “Seven Latin inscriptions from Rome”. In: Greece \& Rome 20, 75-92.

Haug, Dag (2004). "On unaccented short vowels in Sabellian and the morphology of the Italic 2nd conjugation”. In: Indogermanische Forschungen 109, 235-249.

Hickey, Raymond (2010). The Handbook of Language Contact. Malden, MA [et al.]: Wiley-Blackwell.

Jiménez Zamudio, Rafael (1986). Estudio del dialecto peligno y su entorno lingüístico. León \& Salamanca: Universidad de León \& Universidad de Salamanca.

Lazzarini, Maria \& Paolo Poccetti (2001). Il mondo enotrio tra VI e V secolo a. C. L'iscrizione paleoitalica da Tortora. Atti dei seminari napoletani (1996-1998). Napoli: Loffredo.

Lejeune, Michel (1975). “Réflexions sur la phonologie du vocalisme osque”. In: Bulletin de la Société Linguistique de Paris 70, 233-251.

Leumann, Manu (1977). Lateinische Laut- und Formenlehre. München: Beck.

Lindsay, Wallace M. (1913). Sexti Pompei Festi De verborum significatu quae supersunt cum Pauli epitome. Leipzig: Teubner. Repr. Hildesheim: Olms 1965.

Mancini, Marco (1997). “Nochmals über oskisches sim”. In: Historische Sprachforschung 110, 109-121. 
Mancini, Marco (2006). "Osco aflukad nella defixio Vetter 6". In: Samnitice loqui. Scritti in onore di A. L. Prosdocimi per il premio 'I Sanniti’. Ed. by Domenico Caiazza. Piedimonte Matese: Libri di arte scienza e cultura della Banca Capasso Antonio, 73-90.

Marinetti, Anna (1985). Le iscrizioni sudpicene. Vol. 1: Testi. Firenze: Olschki.

Meiser, Gerhard (1986). Lautgeschichte der umbrischen Sprache. Innsbruck: Institut für Sprachwissenschaft.

Meiser, Gerhard (1987). "Pälignisch, Latein und Südpikenisch”. In: Glotta 45, 104-125.

Meiser, Gerhard (1998). Historische Laut- und Formenlehre der lateinischen Sprache. Darmstadt: Wissenschaftliche Buchgesellschaft.

Nishimura, Kanehiro (2004). “Development of the prevocalic *m in Latin”. In: Glotta 80, 231-250.

Nishimura, Kanehiro (2005). "Superlative suffixes *- ismo- and *-ismmo- in Sabellian languages". In: Glotta 81, 160-183.

Nishimura, Kanehiro (2013). "Vowel reduction and deletion in Sabellic". In: Commentationes Iranicae. Vladimiro f. Aaron Livschits nonagenario donum natalicium. Sbornik statej $\mathrm{k}$ 90-letiju Vladmira Aronoviča Livšitsa. Ed. by Pavel Lurje \& Sergei Tokhtas’jev. Copenhagen: Nestor-Istorija.

Nishimura, Kanehiro (2014). "On accent in the Italic languages: nature, position, and history”. In: Studia Linguistica Universitatis lagelloniae Cracoviensis 131, 161-192.

Pezzini, Giuseppe (2011). “Contraction of est in Latin”. In: Transactions of the Philological Society 109, 327-343.

Rix, Helmut (1992). Historische Grammatik des Griechischen. Laut- und Formenlehre. 2nd ed. Darmstadt: Wissenschaftliche Buchgesellschaft.

Rix, Helmut (1993). “Osk. úpsannam - uupsens und Zugehöriges”. In: Sprachen und Schriften des antiken Mittelmeerraums. Festschrift für Jürgen Untermann zum 65. Geburtstag. Ed. by Frank Heidermanns, Helmut Rix \& Elmar Seebold. Innsbruck: Institut für Sprachwissenschaft der Universität Innsbruck, 329-348.

Rix, Helmut (1997). “The Pre-Lucanian inscriptions of Southern Italy”. In: Festschrift for Eric $P$. Hamp. Ed. by Douglas Q. Adams. Vol. 2. Washington, DC: Institute for the Study of Man, 144-154.

Rix, Helmut (2003). “Ausgliederung und Aufgliederung der italischen Sprachen”. In: Languages in Prehistoric Europe. Ed. by Alfred Bammesberger \& Theo Vennemann. Heidelberg: Winter, 147-172.

Rix, Helmut (2009). “Umbro e sudpiceno”. In: L'umbro e le altre lingue dell'Italia mediana antica. Atti del I Convegno Internazionale sugli Antichi Umbri, Gubbio, 20-22 settembre 2001.

Ed. by Augusto Ancillotti \& Alberto Calderini. Perugia: Jama, 249-264.

Seidl, Christian (1994). "Gemeinsabellisch und Vulgärlateinisch: Der Vokalismus”. In: Tocharisch. Akten der Arbeitstagung der Indogermanischen Gesellschaft, Berlin, September 1990.

Ed. by Bernfried Schlerath. Wiesbaden: Reichert, 349-370.

Sen, Ranjan (2012). "Reconstructing phonological change: duration and syllable structure in Latin vowel reduction". In: Phonology 29, 465-504.

Sommer, Ferdinand \& Raimund Pfister (1977). Handbuch der lateinischen Laut- und Formenlehre. Vol. 1: Einleitung und Lautlehre. 4th ed. Heidelberg: Winter.

Thomason, Sarah G. (2003). "Contact as a source of language change”. In: The Handbook of Historical Linguistics. Ed. by Brian D. Joseph \& Richard D. Janda. Oxford: Blackwell, 687-712. Thomason, Sarah G. \& Terrence Kaufman (1989). Language Contact, Creolization and Genetic Linguistics. Berkeley, Los Angeles \& Oxford: University of California Press.

Untermann, Jürgen (1990). Rev. of Meiser 1986. In: Indogermanische Forschungen 95, 292-298. 
Untermann, Jürgen (2000). Wörterbuch des Oskisch-Umbrischen. Heidelberg: Winter.

Von Planta, Robert (1892-1897). Grammatik der oskisch-umbrischen Dialekte. 2 vols. Strassburg: Trübner.

Walde, Anton \& Johann B. Hofmann (1938-1956). Lateinisches Etymologisches Wörterbuch. 2 vols. Heidelberg: Winter.

Wallace, Rex E. (2008). Zikh Rasna: a Manual of the Etruscan Language and Inscriptions. Ann Arbor \& New York: Beech Stave Press.

Weiss, Michael (1993). Studies in Italic Nominal Morphology. PhD thesis. Ithaca: Cornell University Press.

Weiss, Michael (1998). “On some problems of final syllables in South Picene”. In: Mír Curad. Studies in honor of Calvert Watkins. Ed. by Jay H. Jasanoff, H. Craig Melchert \& Lisi Oliver. Innsbruck: Institut für Sprachwissenschaft, 703-715.

Weiss, Michael (2009). Outline of the Historical and Comparative Grammar of Latin. Ann Arbor: Beech Stave.

Zair, Nicholas (forthcoming). “The origins of - urC- for expected - orC- in Latin”. In: Glotta.

Zair, Nicholas (2014a). "The future perfect in Oscan and Umbrian, and the $\bar{o}$-perfect in South Picene". In: Transactions of the Philological Society 112, 367-385.

Zair, Nicholas (2014b). "The treatment(s) of *-u- after a coronal in Oscan. Dialect variation and chronology”. In: Indo-European Linguistics 2, 112-125.

Zair, Nicholas (2016). Oscan in the Greek Alphabet. Cambridge: Cambridge University Press. 
Brought to you by | University of Cambridge 